$\mathrm{IJIF}$

62

Received 6 February 2018 Revised 10 March 2018 27 June 2018

10 March 2019

21 March 2019

Accepted 21 March 2019

\section{Proposed models for unit trust waqf and the parameters for their application}

\author{
Syahnaz Sulaiman
}

Faculty of Economics and Muamalat, Universiti Sains Islam Malaysia, Nilai, Malaysia

Aznan Hasan, Azman Mohd Noor and Muhd Issyam Ismail Institute of Islamic Banking and Finance (IIBF), International Islamic University Malaysia, Kuala Lumpur, Malaysia, and

Nazrul Hazizi Noordin International Centre for Education in Islamic Finance, Kuala Lumpur, Malaysia

\begin{abstract}
Purpose - This paper aims to present the viability of unit trust waqf (Islamic endowment) as an alternative asset class for waqf creation.

Design/methodology/approach - This paper starts with the conceptual exploration of the literature in the areas of waqf. The sources of the literature cover authentic sources of the Qur'ān and hadìth, as well as secondary sources such as books, journal articles and online resources.

Findings - This paper provides the conceptual framework of five models of unit trust waqf and their investment management parameters.

Originality/value - The novelty of this paper lies in its attempt to highlight the importance of waqf investment strategy in ensuring sustainable returns for waqf. It does so by introducing the conceptual models of unit trust waqf as viable mechanisms to pool more cash waqf from individual investors. The sustainability of the capital waqf assets in the form of unit trusts is maintained through the parameters for its application proposed towards the end of the paper.
\end{abstract}

Keywords Malaysia, Islamic finance, Waqf, Capital market, Endowment, Unit trust

Paper type Conceptual paper

\section{Introduction}

The institution of waqf is one of the socio-economic institutions in Islam that encourages Muslims to be creative and innovative in generating revenues and providing various goods and services for Muslim societies (Abdel Mohsin, 2013). Waqf institutions are facing the paradox of having huge numbers of waqf properties, yet many are left idle and unproductive, despite the properties being located in prime areas (Ismail, 2012). This issue

(C) Syahnaz Sulaiman, Aznan Hasan, Azman Mohd Noor, Muhd Issyam Ismail and Nazrul Hazizi Noordin. Published in ISRA International Journal of Islamic Finance. Published by Emerald Publishing Limited. This article is published under the Creative Commons Attribution (CC BY 4.0) licence. Anyone may reproduce, distribute, translate and create derivative works of this article (for both commercial and noncommercial purposes), subject to full attribution to the original publication and authors. The full terms of this licence may be seen at http://creativecommons.org/licences/by/4.0/legalcode
ISRA International Journal of Islamic Finance Vol. 11 No. 1, 2019 pp. $62-81$ Emerald Publishing Limited 0128-1976

DOI 10.1108/JJIF-02-2018-0019 
has sparked the attention of waqf managers and policymakers as well as Islamic financial institutions of the need to transform unproductive waqf assets into high quality and incomeproducing properties. The recent call for waqf revival, as well as the renewed public attention and awareness of it, is indeed crucial factors for the rapid advancement of the Islamic philanthropy sector.

There are a number of waqf stakeholder organizations in Malaysia. These include the federal agencies such as:

- JAKIM (Jaabtan Kemajuan Islam Malaysia or Department of Islamic Development Malaysia);

- JAWHAR (Jabatan Wakaf, Zakat dan Haji or the Department of Waqf, Zakat and Hajj) under the Prime Minister Department of Malaysia; and

- Yayasan Waqaf Malaysia (Waqf Foundation of Malaysia).

Equally (or possibly more) important are the State Islamic Religious Councils (Majlis Agama Islam Negeri or SIRC). These agencies have been instrumental in organizing and promoting various programs and research activities to further develop the institution of waqf and to harness its potential for the benefit of the ummah (Muslim nation). Despite these commendable efforts, it has been reported that many waqf lands and buildings in Malaysia are not well managed or are even abandoned. As a result, the institution of waqf in Malaysia remains underdeveloped (Ismail, 2012).

One contributing factor to this problem is that the vast majority of waqf assets in Malaysia comprise immovable properties of low liquidity (Mohsin and Mohammad, 2011). For instance, in 2004 in Selangor alone, real estate waqf accounted for 97 per cent of waqf assets; only 3 per cent were in cash (Yang, 2014). This situation is a stark contrast to other countries such as Singapore (a Muslim-minority country) and Kuwait (a Muslim-majority country) where, respectively, 13 per cent and 41 per cent of their waqf assets are in cash deposits and other capital instruments. In fact, the pool of fixed waqf assets in Malaysia is much higher than some reputable endowments in Europe such as Harvard University (25 per cent of their endowments are in real assets) (Harvard University, 2013) and Yale University (28 per cent of their endowments are in real assets) (Yale University, 2013).

Other than that, the prospective of the waqf institution as a source of wealth creation is also potentially hindered by numerous issues. One of them is the lack of funds faced by mutawallis (waqf managers) (Mahamood, 2006a, 2006b; Mohd Salleh and Muhammad, 2008; Ahmad and Muhamed, 2011; Sulaiman, 2012). This is because sufficient funds, particularly in the form of highly liquid waqf assets, are desperately needed by the mutawallis to enable them to manage the waqf assets towards realizing the waqf's ultimate objective of serving the needs of the ummah (Zarqa, 1994). This "asset-rich, cash-poor" syndrome that has been suffered by many waqf establishments in Malaysia (Abdul Karim, 2011) is indeed serious. According to a report published by Yayasan Waqaf Malaysia (2016), only 11.4 per cent of the total 31,000 hectares of waqf lands throughout the country in 2016 have been developed; the remainder is sitting idle.

Therefore, the prospect of investing waqf assets in highly liquid financial instruments must be explored by the stakeholders; in fact, it should be given utmost priority. Up to this point, the number of waqf investments and Sharīah-compliant products available in the capital market are still limited. Most of the time, waqf managers are left with no choice but to keep the waqf proceeds in Islamic fixed deposits. It is thus timely for this alternative option to be given full consideration, 
particularly as commercial Islamic financial institutions have shown interest in being involved in the national waqf development agenda.

As such, this paper attempts to explore the viability of integrating waqf with Islamic unit trust, a modern financial instrument that is not only Sharī'ah compliant but also carries high potential for competitive returns while at the same time preserving the initial capital. Through this instrument, the current waqf asset portfolios could be diversified instead of being concentrated or frozen in non-flexible instruments and assets. Notwithstanding the exciting prospects offered by Islamic unit trust funds, the practice of unit trust waqf is still at the inception stage, calling for more in-depth studies to explore its practicality from the legal and Sharīah perspectives.

The rest of this paper is structured as follows. The second section explores the literature pertaining to the concept of waqf and its related issues. These include, among others, its role in the sustainability and well-being of the ummah, how it should be managed and governance issues. The discussion also deals with Sharī'ah rulings on unit trust waqf, which hinge upon the permissibility of cash waqf and temporary waqf. It further deals with the recent development of the unit trust industry in Malaysia and sustainable waqf investment strategies. The section thereafter proposes the models of unit trust waqf. The study then explains the parameters for application of unit trust waqf, particularly in addressing several important issues such as istibdāl (substitution) and risk management strategy. The paper ends with the conclusion.

\section{Literature review \\ Concept of waqf}

According to Ibn Qudāmah (1998), waqf means "withholding the corpus of an asset [without disposing of it] and distributing its return". Under the principle of qurbah (piety), waqf is the act of endowing one's property for charitable purposes to get rewards from Allah (SWT) in the hereafter (Kahf, 2003). Apart from the relationship between human beings and their Creator, waqf also relates to people's affairs among themselves in the spirit of love, brotherhood and cooperation (Sulaiman, 2008). According to Nadwi (2015), the institution of waqf primarily serves two objectives. First, in spiritual terms, waqf provides a vehicle for a perpetual reward for the donor. Second, it confers numerous socio-economic benefits to the community in general, particularly to the underprivileged. Therefore, waqf, which is referred to as șadaqah järiyah (ongoing charity) in a hadìth (Muslim, 1998), is more attractive to Muslims, as it provides them perpetual rewards in the afterlife as compared to conventional endowment where the benefits are only obtained in this world. The perpetual or continuous feature of waqf is further manifested through a progressive approach in developing waqf property. No waqf asset should be left idle; it must be attended to to ensure sustainable returns to the beneficiaries (Hasan and Sulaiman, 2016) in addition to its survival. Likewise, Kahf (1999) asserted that the recurring benefits generated from waqf can be used as a mechanism to increase the standard of living of the ummah and reduce poverty and difficulties among the poor and needy.

\section{Waqf for sustainability and well-being of the ummah}

Waqf has been contributing towards the promotion of well-being and social development of nations since its inception. It particularly flourished during the golden age of Islam. It was once recognized as one of the world's most influential third-sector institutions (Sadeq, 2002; Arshad and Haneef, 2015). The historian Hodgson (1974) characterized it as "a vehicle for financing Islam as a society". Waqf serves as an 
important and effective tool for raising adequate capital to be channelled to fund various economic and social activities in a sustainable manner. In fact, a similar concept to waqf was adopted in Europe with the establishment of world-famous educational endowments such as Merton College, University of Oxford (Arjomand, 1998). Waqf's success not only inspired the formation of today's modern not-for-profit organizations and non-governmental organizations (NGOs) but also has left some influence in the determination of their organizational objectives.

Waqf is argued to have a broader spectrum of social and economic development than other philanthropic and redistributive instruments such as zakat (almsgiving), șadaqah (charity) and hibah (gift), which are mainly involved in helping the poor and needy only. The use and purpose of waqf cover:

- religious activities (Mohammed Noor et al., 2014);

- provision of public infrastructure such as hospitals, universities and libraries (Çizakça, 1998; Van Leeuwen, 1999; Hassan, 2007);

- $\quad$ education (Gaudiosi, 1988, Hadi, 2009; Raja Ramli and Abdul Hamid, 2014);

- $\quad$ poverty alleviation (Khan, 2010; Shahimi et al., 2013; Saifuddin et al., 2014; Shirazi, 2014); and

- employment (Ahmad and Muhamed, 2011; Mohd Ramli and Jalil, 2014).

It thus serves to fulfil a broad spectrum of societal needs (Mohammed Noor et al., 2014).

One of the significant features of waqf is that it provides flexibility of fund utilization as compared to zakat. Zakat funds must be used for specific categories of recipients. On the contrary, waqf funds can be used to provide a wide range of welfare services for both Muslims and non-Muslims. Waqf beneficiaries can also be extended to other living beings in fulfilling specific initiatives such as animal protection and environmental conservation. It can also reduce the cost to government of fulfilling public needs such as building and maintaining public infrastructure (Çizakça, 1998; Abdel Mohsin, 2013).

Another focus of discussion on the contemporary application of waqf concerns the sustainability of waqf institutions. Dafterdar (2011) argued that sustainability of waqf is an added bonus or a complement to the profitability generated by waqf. This is because the surplus generated from profit-making activities can be used to sustain the provision of social services. Sole reliance on cash donations for waqf - while not hedging against the decline of purchasing power of money received - could increase the exposure of waqf institutions to the risk of closure. Mohsin et al. (2016) opined that the preservation of benefits for the intended beneficiaries can be attained through prudent and efficient investment and development of waqf assets. Meanwhile, Sulaiman and Zakari (2015) emphasized the importance of diversifying the sources of income for waqf institutions alongside the important role played by investment managers in safeguarding the value of the waqf investment funds over time. In fact, diversification of waqf sources by venturing out into the contemporary forms of wealth like cash and shares could increase the flexibility of waqf and public participation in it. For instance, this can be done through investing waqf proceeds in the less volatile and balanced unit trust portfolios, whose underlying assets are mostly fixed income and stable asset classes such as șukuk and money market instruments.

This paper further presents how waqf as a social finance vehicle can contribute as a complementary alternative to governments and private-sector financial institutions which cannot undertake many socially desirable projects because of lack of funds or commercial non-viability. 
Traditionally, the waqf institution has been considered similar to a non-profit trust (Çizakça, 2014). In regard to the administration and governance of waqf in contemporary times, many scholars emphasize the importance of professional management and transparent administration of waqf to ensure its effective outcomes. Alpay and Haneef (2015) accentuate that the transparency and accountability of the funding as well as the implementing agencies are crucial for waqf to achieve its ultimate goal of poverty reduction. In the same line of thought, Hassan and Shahid (2010) argue that professional business management would improve the institutional quality, service delivery and effective delegation of the responsibilities, thus facilitating accountability of the waqf management.

Hence, a sound corporate structure is important in ensuring that the waqf is managed professionally and able to operate in perpetuity. Sulaiman and Abdul Manaf (2009) argue that transparency is vital not only in the operation of the management of waqf but also in its reporting, as it reduces the discrepancy between the donors and the waqf administration. Thus, under the management of, for instance, a professional fund manager, waqf management would have better accountability and transparency towards adding value and promoting wealth (Mohd Ramli and Jalil, 2014).

\section{Definition of unit trust and the recent development of unit trust waqf applications}

An Islamic unit trust fund (also known as an Islamic mutual fund) is a type of collective investment scheme that offers investors the opportunity to invest in a diversified portfolio of Sharīah-compliant securities, șukukk, money market instruments, real estate or commodities. This type of fund is determined by the assets or constituents of the portfolio. They determine its risk and the kind of investors the fund is targeting. Fundamentally, there are three varieties of unit trust funds: Islamic equity funds (which deal in shares), șuku $k$ funds (fixed income funds which are relatively more stable) and money market funds (Securities Commission Malaysia, 2019). An Islamic unit trust fund is managed by professional fund managers who invest the money that is collected in a diversified portfolio of Sharíahcompliant financial instruments, depending upon the objective of the fund. Investors can earn income from the investment in an Islamic unit trust fund through capital gains and/or distribution of income.

In Malaysia, the market capitalization of Islamic unit trusts has shown a significant improvement over the past several years. The net asset value of Islamic unit trust funds has posted tremendous growth since the financial crisis. It went from US\$5.27bn in 2009 to US \$21.3bn as at January 2019 (Securities Commission Malaysia, 2019). The recent statistics provided by the Securities Commission Malaysia (SC) also show an increased number of Sharīah-compliant funds from only 17 out of a total of 127 funds in 2000 to 229 out of total 666 funds in 2019. This was paralleled by a tripling in the number of management companies from 13 companies in 1992 to 39 companies as at January 2019. The huge size of Islamic unit trust funds in Malaysia, which is estimated at US\$21.3bn (Securities Commission Malaysia, 2019), presents a significant opportunity to create a viable and sustainable Islamic social financing source through a unit trust waqf framework. The proposed mechanics of this new type of waqf would provide an avenue for unit trust investors or unitholders to endow a portion of the units or the dividends.

The concept of waqf for mutual funds or unit trusts is not new. In 2004, Dompet-Dhuafa Batasa Syariah Waqf Fund was first introduced in Indonesia on fixed-income basis. Up to 80 per cent of the fund was allocated in șukük and the rest in the Islamic money market (Islamic deposits). The return rate of the fund was between 11 and 13 per cent, and part of the dividend was channelled to waqf (Siswantoro and Dewi, 2011). Unfortunately, the fund was 
terminated and converted to a hajj fund in 2006 due to lack of participation by investors. In addition, the fund was deemed to be ambiguous, relatively small in size with very little promotion, as well as laden with some market risk issues (Siswantoro, 2017, personal communication, 31 April). Ten years later, Dompet Dhuafa, a well-known waqf institution in Indonesia, in collaboration with BNI Asset Management, established a Sharī'ah-compliant mutual fund with a special waqf feature. This new fund of BNI-AM Dana Dompet Dhuafa, which was actually a rebranding of the previous Batasa Syariah Fund, provided an avenue for unitholders to endow some of the dividends for waqf purposes. As the fund manager, BNI Asset Management not only attracted more investors but also managed to allocate onethird of the management fees to a waqf fund (HS Dalimunthe, 2017, personal communication, 1 May). In terms of fund allocation, about 98 per cent was allocated in corporate $s u k \bar{u} k$, while the remaining 2 per cent was invested in Sharī'ah-compliant deposits.

To spur a similar initiative of unit trust waqf in Malaysia, this drive could probably be initiated by Permodalan Nasional Berhad (PNB), a government-linked fund manager. As on 30 November 2018, PNB's current assets under management (AUM) were recorded at US $\$ 72.1 b n$ (Permodalan Nasional Berhad, 2018). PNB's resilient financial performance through the Sharíah-compliant unit trusts, Amanah Saham Nasional (ASN) and Amanah Saham Bumiputera (ASB), have demonstrated a large potential to have the unit holders to put aside a portion of the units or dividends for waqf. ASB and ASN funds, which are guaranteed by the Malaysian Government, have been pronounced Sharī'ah compliant by the National Fatwa Committee along with many State Fatwa Committees, namely, Wilayah Persekutuan Kuala Lumpur, Selangor, Penang, Terengganu, Kelantan and Negeri Sembilan. A unit trust waqf could potentially be a viable model as waqf can be created at a minimal cost, thus giving everyone the opportunity to create waqf. Therefore, in this context, waqf can be explored as a source of funding by waqf institutions and fund managers, due to its potential as a perpetual pool of funds for their social programs.

\section{The legitimacy of cash waqf and other financial assets including unit trust}

The majority of Muslim jurists consider cash waqf to be legitimate. From the Hanafī School, a disciple of Abu Hanifah, Imam Zufar approved all movable properties to be dedicated as waqf. He included the waqf of dirhams and dinars (cash waqf) as the capital in business dealings based on muda arabah, the return of which can be directed to the charitable purposes of the waqf (Al-Tarābulsī, 1902; Ibn al-Humām, 1988; Ibn 'Ābidīn, 2003). In addition, both Imam Muhammad al-Shaybānī and Abū Yūsuf (Ibn 'Ābidīn, 2003) approved all types of movable properties as the subject matter for waqf. Imam Mālik bin Anas also agreed on both immovable and movable properties as a subject matter of waqf even if it is cash waqf. Cash waqf, which is based on a loan without interest, is permissible according to Mālikī jurists (Al-Ābi 1970). With respect to the other two schools of fiqh (Islamic jurisprudence), both Imams al-Shāfi ' 1 and Ibn Hanbal also agreed on the validity of both immovable and movable properties as subject matter of waqf (Abū Zuhrah, 1959; Al-Zuhayli, 2002).

In the modern application of waqf, movable assets in the form of cash and other financial assets have been widely accepted by Muslim jurists. Financial assets refer to intangible properties that represent a claim on ownership of an entity or contractual rights to future economic benefits that may flow to the owner. In other words, a financial asset represents the contractual right to receive cash or other financial assets (Bouheraoua et al., 2014). Common types of financial assets include shares, șukuk and unit trusts. This provision enables people to contribute in establishing a waqf even if they do not personally own any real estate. The permissibility of making waqf using contemporary forms of wealth like 
cash, shares and unit trusts increases the flexibility of waqf and public participation in funding it.

The permissibility of unit trust as the subject matter of waqf was never specifically discussed by classical Muslim scholars. Hence, it is extremely necessary for the fatwa authorities as well as contemporary Muslim scholars to provide the interpretations on its permissibility according to the Sharīah to set the direction of its future implementation. There is only one Shari' ah resolution concerning the permissibility of endowing unit trusts. In 2009, the International Islamic Fiqh Academy in its 19th meeting, held in the United Arab Emirates (UAE), resolved the permissibility of waqf in the form of financial instruments as follows: "It is permissible to endow shares (that are Sharī'ah compliant), sukük, intangible rights, benefits and unit trusts, as they are all assets recognized by Sharī ah" (International Islamic Fiqh Academy, (2009), Resolution No. 181 (7/19).

For the purpose of this study, the fatwas and discussions on the permissibility of cash waqf and waqf shares are relevant as they are strongly related to unit trusts, which are themselves likely to be constituted of shares, sukuk, or any other Sharíah-compliant securities. In conceptualizing the viable models of unit trust waqf, this study has also used the concepts of cash waqf and waqf shares.

\section{The legality of temporary waqf}

Waqf mu'aqqat refers to the act of endowing assets for a specific period, after which they shall be returned to the original owner (wäqif). Classical Islamic jurists had differing opinions on this matter. The majority prohibited the practice of temporary waqf as it does not satisfy the condition of being perpetual, hence nullifying what they considered to be the fundamental nature of waqf (Al-Zuhayli, 2002).

However, temporary waqf is allowed by the Mālikī School, which opined that the permanent transfer of ownership is not a condition for a valid waqf (Al-Dardīr, 1991). Thus, they allowed endowing an asset for a specific period and having it returned to the original owner after the period ends (Al-Dardīr, 1991). For instance, a wāqif may specify to endow his house for a month; therefore, the ownership of the house shall be returned to him after the end of that period.

Temporary waqf is also allowed by some Shāfi î̀ scholars (Al-Bujayrimī, 1995) in the sense that any particular beneficiary may receive the benefit of the waqf temporarily; however, according to this view, the ownership of the waqf will never return to the wäqif. For example, in the case of a house endowed as a waqf, any particular beneficiary may be replaced by another beneficiary after a period and so on. Temporary waqf, however, is not allowed for the waqf of mosques and cemeteries.

Kahf (2003) argues that although the principle of perpetuity is of high importance for waqf, the concept is sometimes carried too far to an extent that it restricts certain acts of benevolence, particularly in today's world. Temporary waqf should be encouraged as sometimes it is needed in a few cases, for example in providing scholarship for students until graduation or maintaining an orphan until maturity.

Considering the potential of temporary waqf, and with the Māliki precedent of considering it permissible, many fatwas have been issued by contemporary Sharī' ah authorities allowing it, among others:

- International Islamic Fiqh Academy, Resolution No. 181 (7/19), in its 19th meeting in 2009 (the United Arab Emirates);

- AAOIFI Sharī'ah Standard No. 33, Clause 3/1/4; and

- Selangor Fatwa Committee (Malaysia) 1/2014, 4. 

to the jurisdiction of the states. Hence, all affairs relating to waqf in Malaysia are administered by 14 different SIRCs or Majlis Agama Islam Negeri. That SIRCs act as the sole trustee for all waqf properties in every state is evident in all state enactments/acts. The SIRC, as the mutawalli (sole trustee), is responsible for preserving waqf properties, maximizing their revenues and distributing them. As such, remarkably, temporary waqf is legally possible to be practised within the current Malaysian legal framework.

Generally, a number of the state enactments allow for financial assets such as shares and unit trust to be endowed. One clear-cut example is in Section 10, Enactment Waqf (Perak) 2015, which illustrates the permissibility of unit trust being the subject matter of waqf, based on the definition of waqf of shares that also include "unit trusts". In addition, the provisions of waq mu' aqqat are traceable in a number of State Enactments such as:

- Section 17 of the Rules of Waqf Johor 1983;

- Section 2 of the Administration of Islamic Law (Federal Territories) Act 1993;

- Section 2 of Majlis Sarawak Ordinance 2001; and

- $\quad$ Enactment Waqf (Terengganu) 2016.

Most explicitly, the recent Enactment Waqf of Terengganu 2016 recognizes the applicability of "wakaf muaqqat" which is defined by the enactment as "a waqf dedication for a specific period of time".

These legal provisions demonstrate that the modern application of waqf via contemporary financial assets and contemporary mechanisms has been recognized by a number of state authorities in Malaysia. Nevertheless, its application is yet to be tested within the current Islamic finance legal framework.

\section{Sustainable waqf fund investment strategy}

Diversification is one of the key strategies in investments, as manifested by the popular saying, "Don't put all your eggs in one basket." This strategy is meant to ensure that investors will still get return from certain segments should any other segment lose its momentum with little or no return at all. According to Jim Garland, in the context of preserving the capital such as in a waqf fund, the most important strategy is to optimize the return for the beneficiaries rather than focusing on the capital appreciation (Dimson, 2007). Waqf funds left in a typical saving account are exposed to inflation risk that can be detrimental to the value of the fund in the long run (Wildermuth, 2012). As such, the best investment strategy is not merely to maintain the capital but also to consider the declining purchasing power of the waqf (Wildermuth, 2012). It is worth observing that in managing risks, only generated profits would be distributed to beneficiaries while preserving the original capital amount. Hence, portfolio rebalancing and active portfolio management are crucial to ensure the sustainability of waqf capital.

There are three important criteria that need to be addressed when managing waqf investments. First, the waqf capital should not be diminished; hence, protection of the capital should be a priority. Second, investments undertaken must be able to produce a stable and consistent income to be distributed to waqf beneficiaries for the waqf to be sustainable and to reap endless rewards from Allah (SWT). Third, all investments made for the waqf must be Sharī ah compliant.

Kuwait Awqaf Public Foundation (KAPF) is an organization that is actively involved in managing waqf assets via contemporary approaches. It highlights three important criteria in 
waqf investment strategy, namely, the investments must be based on the Shari' ah, and they must take into consideration the economic and diversification dimensions. To ensure this, the investment activities of KAPF focus on minimizing the risk to safeguard the waqf capital. Feasibility studies are prepared for any investment project, and investments are diversified in terms of location as well as portfolios and sectors including financial, real estate and services. Moreover, investment ceilings are defined for each sector (Al-Busharah, 2012).

Meanwhile, the International Islamic Fiqh Academy (2004) in Resolution no. 140 (6/15) in Muscat spelled out some important guidelines for waqf investment strategies that can be summarized as follows:

(1) comply with Sharī'ah principles;

(2) generate stable income while preserving waqf capital;

(3) diversify the investment portfolio to minimize the risk of loss;

(4) use various hedging mechanisms to avoid decline or loss of waqf capital;

(5) conduct comprehensive research before investing in projects to ensure high success and great impact on the economy;

(6) use prudent investment tools and avoid high-risk investments;

(7) the investment method should be consistent with the nature of the waqf asset in maintaining the capital and ensuring the return to beneficiaries;

(8) the ownership of movable waqf properties should be preserved from loss of ownership or illegal transfer;

(9) if the movable waqf properties are in cash form, they should be invested in contracts such as mud̄arabah, mushärakah, istișna' and other contracts; and

(10) the investment manager should be transparent in terms of reporting the operations, revenues and benefits distribution.

\section{Research design}

This study is qualitative in nature and uses document research as the main method of analysis sourced from books, fatwa compilations, journal articles and other published sources. Based on the literature review, this study explores and identifies a number of important underlying themes related to unit trust waqf, as shown in Figure 1, which were used in formulating the relevant conceptual models.

Figure 1 depicts the conceptual framework of this study towards formulating the working models of unit trust waqf. First, the models are formulated with the objective of providing the possible mechanics for maximizing the benefits that can be potentially generated from cash waqf. Second, unit trust waqf models take into consideration some prudent and balanced investment strategies that are closely linked to the very objective of Islamic endowment, which is to safeguard the principal amount of waqf funds while generating sustainable returns to the beneficiaries. Apart from that, the establishment of unit trust waqf funds looks into cultivating the corporate management of waqf funds, among others, by promoting ethical and professional conduct by highly skilled managers of waqf institutions. Finally, the unit trust waqf models are foreseen to become the alternative models of Islamic social finance in multiplying the generated revenues for the beneficiaries and creating more job opportunities for the benefits of the society through direct engagement with real economic activities.

On the whole, the identification of the themes enables us to recognize some persistent concepts that are crucial towards the establishment of unit trust waqf. This realization will 
ensure that waqf properties are capable of generating continuous revenues for the beneficiaries as well as for the survival and revival of the waqf sector.

\section{Proposed unit trust waqf models}

In the bid to ensure that the ummah's economy will continue to grow, on-going research pertaining to waqf development can be regarded as an evergreen facet of harnessing the creation of new waqf instruments. Fundamentally, the creation of robust and strategic waqf development models can be narrowed down towards achieving three SIRC goals. The first is to convert the scattered and abandoned waqf assets into productive properties. The second is to enhance the performance of existing income-producing assets for better returns for waqf survival as well as for the beneficiaries' benefit. Last, but not least, is to have a wide base for the waqf collection platform to optimize cash waqf collection through feasible structures.

In this section, Figures 2 through 6 present the proposed five models of unit trust waqf implementation.

In Figure 2:

- Step 1: The wäqif buys units from a unit trust then endows the units purchased by him or her.

- Step 2: The ownership of endowed units is held by the State Islamic Religious Council (SIRC) as the mutawalli, which is the sole trustee of the waqf.

- Step 3: The fund manager is responsible to invest the waqf-unit trust and manage the investment portfolio.

- Step 4: The investment returns will be distributed to beneficiaries. Where applicable, some portions of the returns are channelled for reinvestment purposes.

In Figure 3:

- Step 1: The wāqif endows the units purchased by him or her from a unit trust for a pre-determined period.

- Step 2: The ownership of the endowed units is held by the SIRC as the mutawalli, which is the sole trustee.

- Step 3: The fund manager is responsible to invest the endowed units and manage the investment portfolio.

- Step 4: The investment returns will be distributed to beneficiaries. Where applicable, some portions of the returns are channelled for reinvestment purposes.

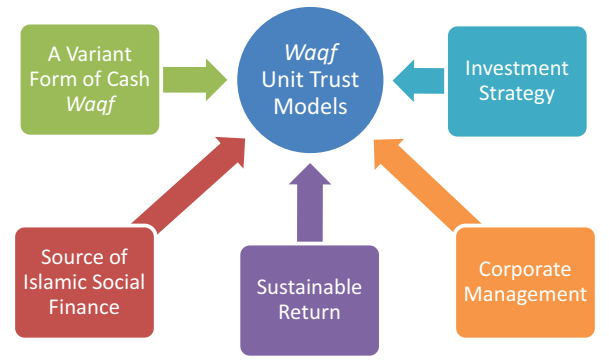

Source: Authors' own

Figure 1.

Conceptual framework of unit trust waqf models 


\section{IJIF \\ 11,1}

72

Figure 2.

First proposed model: unit trust model

Figure 3.

Second proposed model: waqf mu'aqqat model

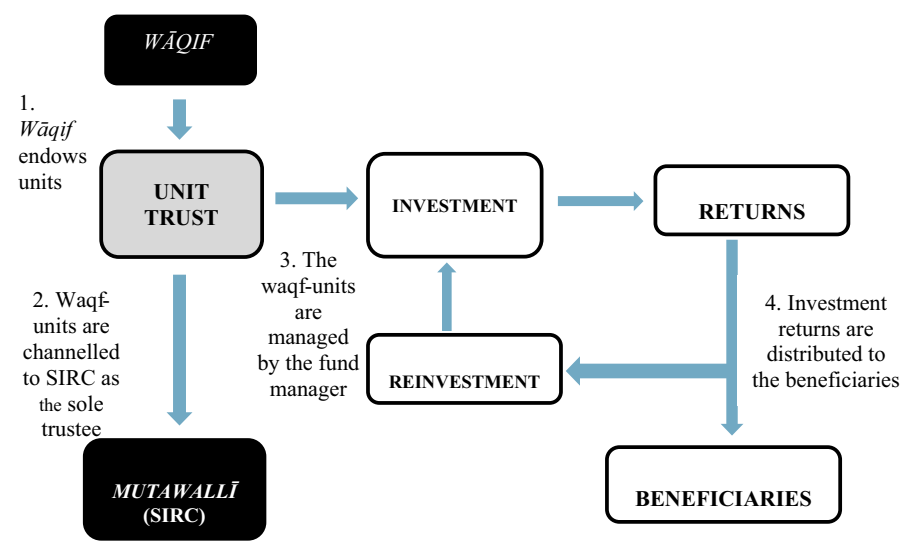

Source: Authors' own

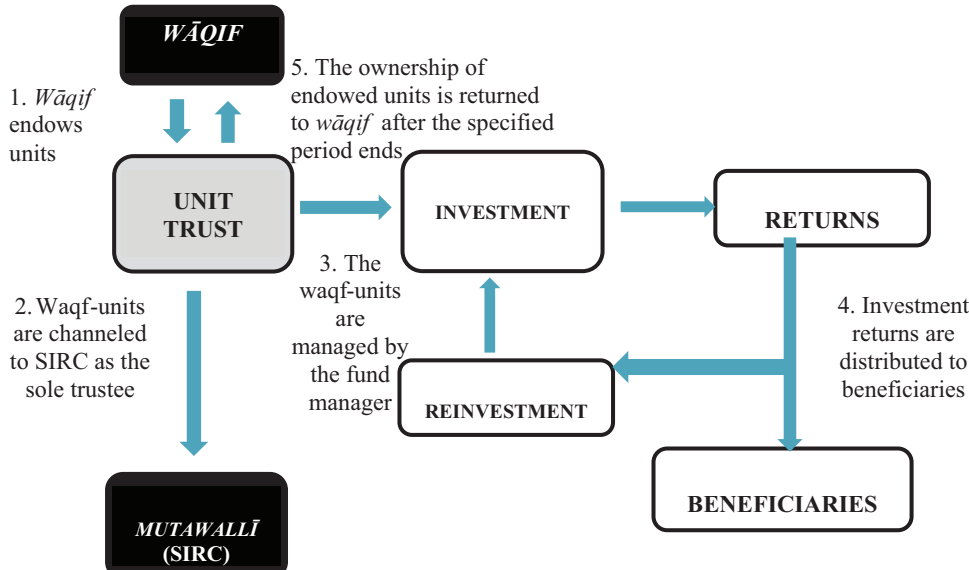

Source: Authors' own

- Step 5: After the waqf period ends, the ownership of the endowed units is returned to the original owner (wäqif).

In Figure 4:

- Step 1: The wāqif endows cash with the stipulation that the proceeds must be used to purchase units that are offered by the unit trust fund manager (hence, the purchased units will be declared as waqf assets, not the cash).

- Step 2: The proceeds will be used to purchase units in the unit trust fund and the ownership will be held by the mutawalli as the sole trustee. 
- Step 3: The fund manager is responsible to invest the endowed units and manage the investment portfolio.

- Step 4: The investment returns will be distributed to beneficiaries. Where applicable, some portions of the returns will be reserved for reinvestment purposes.

In Figure 5:

- Step 1: Investors invest in a unit trust fund (but do not endow the units).

- Step 2: The fund manager is responsible to manage the investors' investment portfolio.

- Step 3: Returns or dividends from the unit trust investment will be channelled to waqf and a partial amount will be used to purchase other units, which later will be declared as waqf and held by the mutawalli.

In Figure 6:

- Step 1: The fund managers endow the full or partial amount of the management fees that they have received and give a condition that the proceeds must be used

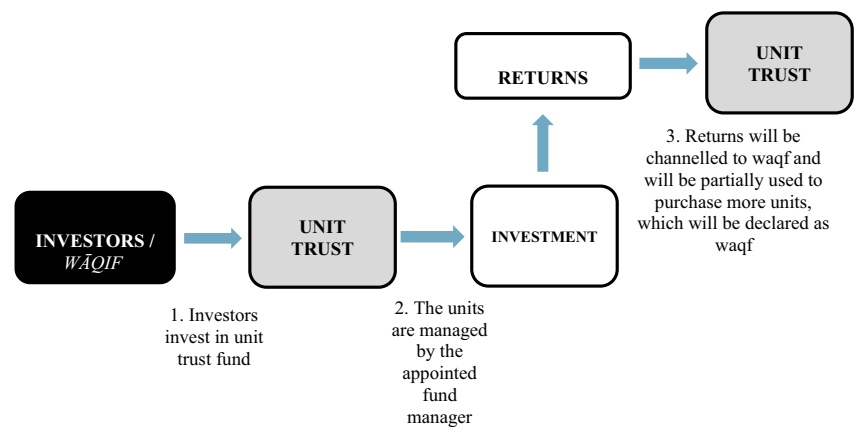

Source: Authors' own

Figure 4.

Third proposed model: cash waqf for the purpose of purchasing units in a unit trust fund

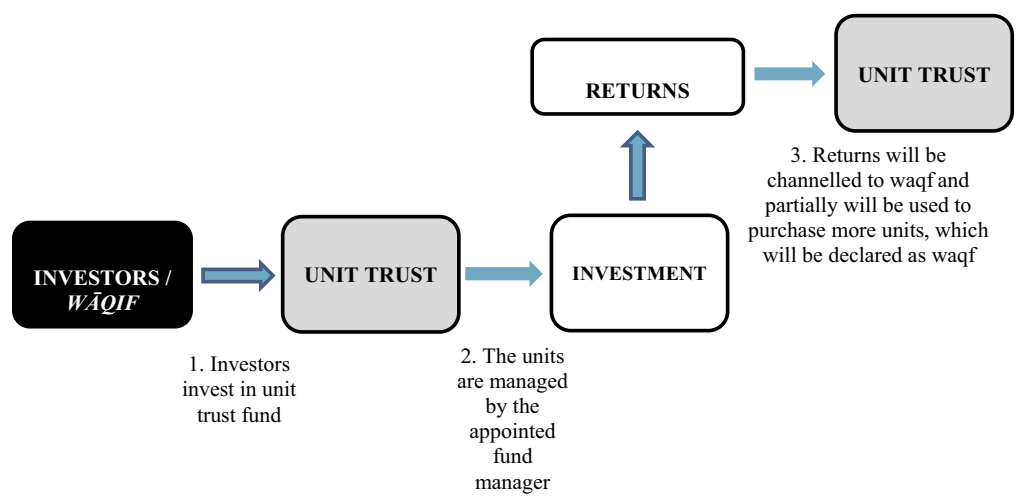

Source: Authors' own

Figure 5.

Fourth proposed model: waqf of dividends 
$\mathrm{IJIF}$

11,1

74

to purchase unit trust (hence, the purchased units will be declared as waqf assets, not the cash).

- Step 2: The proceeds will be used to purchase units in a unit trust fund that will be held by the mutawalli as a sole trustee.

- Step 3: The fund manager is responsible to invest the endowed units and manage the investment portfolio.

- Step 4: The investment returns will be distributed to beneficiaries. Where applicable, some portions of the returns will be reserved for reinvestment purposes.

\section{Proposed parameters for implementing unit trust waqf}

There are a number of issues that might arise related to the implementation of unit trust waqf. The issues include the fund's compliance with Sharī ah principles, supervision and governance of the fund, risk management of the portfolio to preserve the waqf capital from losses, and sustainability of the fund. Hence, to address this concern, this study further proposes the parameters for implementing unit trust waqf, which could be a useful reference for the stakeholders. These include the wāqif (donor), the mutawalli (administer of waqf), fund managers and Shari' ah advisors. These parameters are designed to ensure the adherence of unit trust waqf activities to Shari ah principles and the existing waqf laws and regulations in Malaysia.

The proposed parameters are divided into several sections:

- legality of unit trust waqf from the standpoint of Sharī'ah and waqf laws and regulations in Malaysia;

- supervision of unit trust waqf investment;

- risk management; and

- sustainability of unit trust waqf investment.

Table I depicts the parameters for implementing unit trust waqf.

Figure 6.

Fifth proposed model: waqf of the management fees

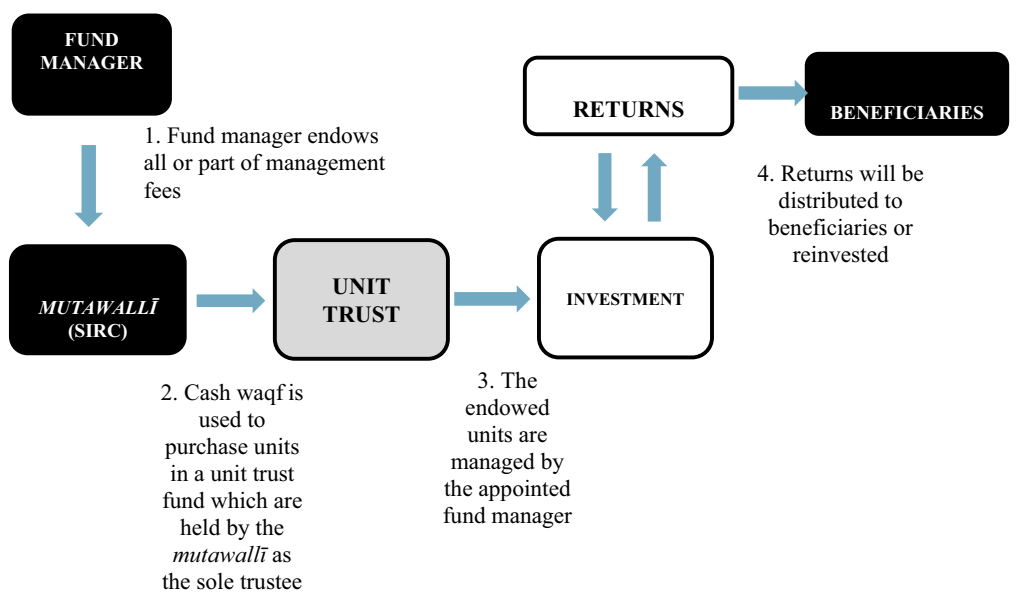

Source: Authors' own 


Parameters
Parameter 1: Sharī'ah
compliance and legality
Parameter 2: Supervision and
oversight

oversight
Description

1/1 - Fund managers must ensure that all investment activities of the unit trust waqf are Sharī' ah compliant. This can be achieved by:

1/1/1 - Meeting the requirements for qualifying as Sharīah-compliant investment set by authoritative bodies such as the Sharīah Advisory Council (SAC) of Securities Commission Malaysia (SC) and that of Bank Negara Malaysia (BNM)

1/1/2 - Establishing a Sharī ah committee which is responsible for reviewing and advising on Sharí ${ }^{-}$ah matters related to the unit trust waqf $1 / 2$ - The entire process of establishing the unit trust waqf, for instance, collection of proceeds, marketing and promotion, investment, istibdā $l$ and distribution of profits must be conducted in accordance to the national and/ or state's legal framework

2/1 - Supervisory and oversight responsibilities related to the governance and administration of the unit trust waqf fund include the following: 2/1/1 - The State Islamic Religious Council (SIRC) acts as the sole trustee (mutawalli $)$ for the unit trust waqf fund

2/1/2 - The mutawalli has duties and responsibilities for supervision and oversight of the administration of the unit trust waqf. SIRCs may appoint any institution to perform the administrative duties on their behalf $2 / 1 / 3$ - The amount of all fees due to the fund managers and their source of payment must be agreed between the mutawalli and the fund managers 2/1/4 - The mutawalli must establish its own supervisory and governance framework to ensure the unit trust waqf funds are properly managed by the appointed fund managers

2/2 - Supervisory and oversight responsibilities related to the collection and distribution activities of unit trust waqf funds include the following: 2/2/1 - The mutawalli must decide which parties should be responsible for the collection and distribution functions of the unit trust waqf. The mutawalli is responsible for supervising the collection and distribution activities of unit trust waqf funds

2/2/2 - Wāqifs must ensure that their money or units which are intended to be endowed are channeled to authorized institutions by the SIRC

$2 / 2 / 3$ - In the event that money is collected from the wa aif for the purpose of investing in unit trust waqf funds, the wäqif must be informed that the proceeds will be used to purchase units in the unit trust funds. Hence, the purchased units will be declared as the waqf assets instead of the cash channeled by the wāqif

2/2/4 - The unit trusts endowed by the wäqif must be Sharī'ah compliant $2 / 2 / 5$ - The appointed fund managers are encouraged to endow some of the management fees received by them to purchase more units for the purpose of waqf

2/2/6 - All promotion and marketing activities associated with the unit trust waqf must correspond with the ultimate objective of waqf and not solely be profit-driven or be biased towards the interest of certain individuals or a group of people

$2 / 2 / 7$ - All relevant information on the unit trust waqf must be provided to the wäqif or investors in a transparent and timely manner

$2 / 3$ - Supervisory and oversight responsibilities related to the investment of unit trust funds include the following:

2/3/1 - The mutawall $i$ has duties and responsibilities for supervision and oversight of the investment activities of the unit trust waqf 2/3/2 - The mutawalli must equip itself with adequate knowledge and

\section{Proposed models for unit trust waqf}

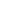
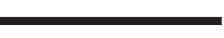
expertise of supervising unit trust waqf investment activities

2/3/3 - to manage the unit trust waqf, the SIRC shall appoint fund managers to manage it for certain fees as agreed upon by both parties 2/3/4 - Fund managers appointed by the mutawalli must have knowledge, expertise and capabilities to manage the waqf funds in such a way that consistent returns can be generated and the initial capital can be protected 2/3/5 - Fund managers must determine the risk tolerance level, investment strategies and governance framework for the unit trust waqf investment, which must be agreed by the mutawalli

$2 / 3 / 6$ - Supervision of unit trust waqf investment activities must be done on an ongoing basis

2/3/7 - Guidelines or clear-cut Standard Operating Procedures (SOPs) for supervision of unit trust waqf investment should be established by the mutawalli

2/3/8 - Report on unit trust waqf investment must be made publicly available

2/3/9 - Effective communication and cooperation between the mutawalli and fund managers are crucial for ensuring the sustainability of unit trust waqf investments

Parameter 3: Risk management 3/1 - Fund managers should establish an effective risk management system and due diligence process

$3 / 2$ - Capital protection must be placed as the ultimate objective of unit trust waqf investments

$3 / 3$ - Unit trust waqf investments must achieve balance between profitability and capital protection

$3 / 4$ - Fund managers are responsible to ensure that unit trust waqf funds are not exposed to extremely high investment risks that can devalue their capital in the long run

$3 / 5$ - Fund managers must ensure that waqf proceeds are not invested in highly volatile asset classes

$3 / 6$ - Fund managers must create highly diversified portfolios of unit trust waqf investments

3/7 - The process of istibdāl (e.g. selling units and using the receipts to purchase other units) in unit trust waqf investments can be done in the following situations:

The wäqif has stipulated that istibdāl must be done through asset trading The unit trust funds experience significant capital loss where high maintenance and management expenditures have to be borne by the mutawalli

The unit trust funds and their constituent assets become Sharī'ah noncompliant

$3 / 8$ - Istibdāl can only be done with the consent of the mutawalli and must

Parameter 4: Sustainability not expose the unit trust waqf funds to high investment risks 4/1 - The mutawalli must balance the primary objectives of sustainability of unit trust waqf investment and distribution of benefits to the waqf beneficiaries

$4 / 2$ - In view of enhancing the sustainability of unit trust waqf funds, the fund managers must take measures that promote sustainable capital growth and ensure consistent returns for the beneficiaries 


Parameters Description

$4 / 3$ - In the event capital deterioration has occurred in previous years, the returns generated in the succeeding years must be used to purchase new units to restore the initial value of unit trust waqf funds (i.e., keep capital intact)

4/4 - The mutawalli must ensure that management fees and other expenditures are paid before returns can be distributed to the beneficiaries $4 / 5$ - Some investment profits may be retained as a capital reserve for the purpose of reinvestment

$4 / 6$ - All promotion and marketing activities related to unit trust waqf investment must be actively conducted 4/7 - Various forms of incentives may be provided to investors or wäqifs such as subsidizing management fees and providing tax rebates

Proposed models for unit trust waqf

Source: Authors' own

\section{Conclusion}

Unit trust waqf is an Islamic financial innovation which could bring tremendous benefits to the waqf institution in Malaysia and other countries, besides those it provides for the waqf beneficiaries. However, the current conversation on unit trust waqf is still theoretical, with little guidance available regarding its implementation. In particular, there is a lack of modern fatwas on the permissibility (or prohibition) of this type of waqf from the Sharīah perspective. As such, this study was conducted to help enrich the relevant literature by shedding some light on its great potential as an investment mechanism that could help to sustain and further develop waqf assets in Malaysia. The real focus, however, is on its application and implementation. This is discussed against the backdrop of the Sharīah rulings on waqf of the asset classes relevant to unit trust. The key issues are the permissibility of endowments of movable assets, particularly cash, and by extension, securities. This is relevant because cash waqf proceeds would be used to purchase units and their underlying constituents such as șukūk and shares.

Our study found that there is no express text in the Qur'ān and Sunnah that explicitly prohibits or sanctions the unit trust waqf. The novelty of this study lies in the proposed models for channeling unit trusts for waqf purposes along with the parameters of their application that could be useful to waqf stakeholders in Malaysia. These could be given full consideration in its future implementation. This study is a part of many efforts from various quarters to promote the application of contemporary waqf, particularly unit trusts as a new category of waqf asset. Finally, and more importantly, unit trust waqf can be a vehicle towards encouraging more philanthropic and charitable activities among members of the society.

\section{References}

Abdel Mohsin, M.I. (2013), "Financing through cash-waqf: a revitalization to finance different needs", International Journal of Islamic and Middle Eastern Finance and Management, Vol. 6 No. 4, pp. 304-321.

Abdul Karim, S. (2011), "Contemporary waqf administration and development in Singapore: challenges and prospect", in Kahf, M. and Mahamood, S.M. (Eds), Essential Readings in Contemporary Waqf Issues, CERT Publications, Kuala Lumpur, pp. 109-128. 
Abū Zuhrah, M. (1959), Muhādarāt fĩ al-Waqf, Dār al-Fikr, Cairo.

Ahmad, S. and Muhamed, N.D. (2011), "Institusi wakaf dan pembangunan ekonomi negara: kes pembangunan tanah wakaf di Malaysia", paper presented at Persidangan Kebangsaan Ekonomi Malaysia ke VI (PERKEM VI), Ekonomi Berpendapatan Tinggi: Transformasi ke Arah Peningkatan Inovasi, 5-7 June, Produktiviti dan Kualiti Hidup, Melaka.

Al-Ābī, Ṣ. (1970), Jawāhir al-Iklīl, Vol. 2, al-Maktabah al-Thaqafiyyah, Beirut.

Al-Bujayrimī, S.M.U. (1995), Bujayrimī 'alā al-Khaț̄īb, Dār al-Fikr, Beirut.

Al-Busharah, K.M. (2012), "Kuwait awqaf public foundation (KAPF): developmental social experience and prospects", paper presented at the Arab Forum Towards A New Welfare Mix: Rethinking the Role of the State, 19-20 December, Market and Civil Society in the Provision of Basic Social Services, Beirut.

Al-Dardīr, A.I.M. (1991), Al-Sharh al-Ṣaghīr, Dār al-Ma rifah, Cairo.

Alpay, S. and Haneef, M.A. (Eds) (2015), Integration of Waqf and Islamic Microfinance for Poverty Reduction: Case Studies of Malaysia, Indonesia and Bangladesh, The Statistical, Economic and Social Research and Training Centre for Islamic Countries (SESRIC) and International Islamic University Malaysia (IIUM), Ankara.

Al-Tarābulsī, B.I. (1902), Al-Is'ā ff fì Ahkām al-Awqaf, al-Mațba ah al-Hindiyyah, Egypt.

Al-Zuhayli, W. (2002), Al-Fiqh al-Istāmī wa Adillatuhu, Vol. 1, Dār al-Fikr, Beirut.

Arjomand, S.A. (1998), "Philanthropy, the law, and public policy in the Islamic world before the modern era", in Ilchman, W.F., Katz, S.N. and Queen II, E.L. (Eds), Philanthropy in the World's Traditions, IN University Press, Bloomington, pp. 109-132.

Arshad, M.N.M. and Haneef, M.A.M. (2015), "Repositioning issues of waqf as a third sector organisation into the mainstream economy", paper presented at Asia Pacific Awqaf Congress, 15-17 April, Sydney.

Bouheraoua, S., Mohamad, S., Kasri, N.S. and Abdullah, S. (2014), "A critical analysis of Sharī' ah issues in intangible assets", ISRA International Journal of Islamic Finance, Vol. 6 No. 2, pp. 157-161.

Çizakça, M. (2014), "The waqf, its basic operational structure, development and contribution”, paper presented at Roundtable Discussion on Development of Waqf Properties in Malaysia, INCEIFIDB/IRTI Workshop, 21 January, Kuala Lumpur.

Çizakça, M. (1998), "Awqaf in history and its implications for modern Islamic economies", Islamic Economic Studies, Vol. 6 No. 1, pp. 43-70.

Dafterdar, M.H. (2011), "Toward effective legal regulations and an enabling environment for inalienable Muslim endowments (awqaf)", Islam and Civilisational Renewal, Vol. 2 No. 4, pp. 654-668.

Dimson, E. (2007), "Endowments volatility and time", paper presented at Nuffield Foundation Investment Seminars, 5 March.

Gaudiosi, M.M. (1988), "The influence of the Islamic law of waqf on the development of the trust in England: the case of Merton College", University of Pennsylvania Law Review, Vol. 136 No. 4, pp. $1231-1261$.

Hadi, A.C. (2009), "Opportunity of productive waqf for financing Islamic higher learning”, Turats, Vol. 5 No. 1, pp. 14-23.

Harvard University (2013), Financial Report: Fiscal Year 2013, Harvard University, Cambridge.

Hasan, A. and Sulaiman, S. (2016), "The use of Islamic real estate investment trust (I-REITs) as a contemporary instrument in developing waqf assets: potential structure, issues and challenges", Intellectual Discourse, Special issue, pp. 521-540.

Hassan, A. and Shahid, M.M.A. (2010), "Management and development of the awqaf assets", paper presented at the Seventh International Conference-The Tawhidi Epistemology: Zakat and Waqf Economy, 6-7 January, Bangi, Selangor. 
Hassan, M.H. (2007), "Explaining Islam's special position and the politics of Islam in Malaysia", The Muslim World, Vol. 97 No. 2, pp. 287-316.

Hodgson, M.G. (1974), The Venture of Islam: Conscience and History in a World Civilization, University of Chicago Press, Chicago.

HS Dalimunthe (2017), personal communication, 1 May.

Ibn, 'Ābidīn (2003), Radd al-Muhtār 'atā al-Durr al-Mukhtār, Vol. 6, Dār al-Amin, Riyadh.

Ibn, al-Humām (1988), Sharh Fath al-Qadīr, Vol. 6, Dār al-Kutub al Ilmiyyah, Beirut.

Ibn, Qudāmah (1998), Al-Mughnī, Dār al-Kitāb al- Arabī, Beirut.

International Islamic Fiqh Academy (2004), "Resolution no. 140 (6/15)", available at: www.iifa-aifi.org/ 2157.html (accessed 12 March 2019).

International Islamic Fiqh Academy (2009), "Resolution no. 181 (7/19)", available at: www.iifa-aifi.org/ 2307.html (accessed at 12 March 2019).

Ismail, C.Z. (2012), "Waqf land development: analysis from legal and application in Malaysia," unpublished doctoral thesis, Department of Shari'ah and Laws, Academy of Islamic Studies, University of Malaya, Kuala Lumpur.

Kahf, M. (1999), "Towards the revival of awqaf: new fiqhi issues to reconsider", paper presented at the Harvard Forum on Islamic Finance and Economics, 1 October, Harvard University, Cambridge.

Kahf, M. (2003), "The role of waqf in improving the ummah's welfare", paper presented the International Seminar on Waqf as a Private Legal Body, 6-7 January, Islamic University of North Sumatra, Medan, Indonesia.

Khan, F. (2010), "Waqf: an islamic instrument of poverty alleviation-Bangladesh perspective", paper presented at the Seventh International Conference-The Tawhidi Epistemology: Zakat and Waqf Economy, 6-7 January, Bangi, Selangor.

Mahamood, S.M. (2006a), Waqf in Malaysia: Legal and Administrative Perspective, Penerbit Universiti Malaya, Kuala Lumpur.

Mahamood, S.M. (2006b), "Waqf laws and some emerging issues", paper presented at National Waqf Convention 2006, 12-14 September, Kuala Lumpur.

Mohammed Noor, A., Ghazali, A.Z. and Mat Rani, M.A. (2014), "The management and development of waqf properties in the state of Kedah Darul Aman", Paper presented at the International Conference on Masjid, Zakat and Waqf (IMAF 2014), 1-2 December, Kuala Lumpur.

Mohd Ramli, A. and Jalil, A. (2014), "Model perbankan wakaf korporat: analisis wakaf Selangor muamalat", Jurnal Pengurusan, Vol. 42, pp. 159-167.

Mohd Salleh, S. and Muhammad, S. (2008), "Waqf development in Malaysia: issues and challenges", Jurnal Pengurusan JA WHAR, Vol. 2 No. 1, pp. 13-36.

Mohsin, A. and Mohammad, M.T.S. (2011), "Weaknesses of current capital raising, financing, and investment methods of awq af (Islamic trusts)”, Economics Development Research (IPEDR) No. 5, Proceedings of the International Conference on Social Science and Humanity, IACSIT Press, Singapore.

Mohsin, M.I.A., Dafterdar, H., Cizakca, M., Alhabshi, S.O., Razak, S.H.A., Sadr, S.K., Anwar, T. and Obaidullah, M. (2016), "The role of waqf in modern economic development", Financing the Development of Old Waqf Properties: Classical Principles and Innovative Practices around the World, Palgrave Macmillan, New York, NY. pp. 21-35.

Muslim, H.. (1998), Sahih Muslim, Islamic Book Service, India.

Nadwi, M.A. (2015), “A new framework of corporate governance for waqf: a preliminary proposal”, Islam and Civilisational Renewal, Vol. 6 No. 3, pp. 353-370.

Permodalan Nasional Berhad (2018), "PNB press release, ASNB declares income distribution for amanah saham bumiputera”, 
$\mathrm{IJIF}$ 11,1

Raja Ramli, R.N.A. and Abdul Hamid, N.A. (2014), "Kelestarian wakaf dalam membangunkan institusi pendidikan: kajian awal", Proceedings of International Conference on Postgraduate Research (ICPR 2014) in Kuala Lumpur, 2014, pp. 454-465.

Sadeq, A.H.M. (2002), "Waqf, perpetual charity and poverty alleviation”, International Journal of Social Economics, Vol. 29 Nos 1/2, pp. 135-151.

Saifuddin, F., Kayadibi, S., Polat, R., Fidan, Y. and Kayadibi, O. (2014), "The role of cash waqf in poverty alleviation: case of Malaysia," in Kuala Lumpur International Business, Economics and Law Conference 4, Economics and Law Conference 4 (KLIBEL4) Proceedings of the International Conference in Kuala Lumpur, Malaysia, 2014, Universiti Sains Islam Malaysia, Nilai, pp. 272-289.

Securities Commission Malaysia (2019), "Summary of statistics-unit trust funds for 2019", available at: www.sc.com.my/analytics/fund-management-products (accessed 7 March 2019).

Shahimi, S., Mohd Marzuki, M.U. and Embong, Z. (2013), "Potential of cash waqf for poverty alleviation in Malaysia: a system dynamics approach”, Jurnal Ekonomi Malaysia, Vol. 47 No. 2, pp. 149-163.

Shirazi, N.S. (2014), "Integrating zakat and waqf into the poverty reduction strategy of the IDB member countries", Islamic Economic Studies, Vol. 22 No. 1, pp. 79-108.

Siswantoro, D. (2017), personal communication, 31 April.

Siswantoro, D. and Dewi, M.K. (2011), "The effectiveness of waqf fund raising through mutual fund in Indonesia", in Kahf, M. and Mahamood, S.M. (Eds), Essential Readings in Contemporary Waqf Issues, Cert Publications, Kuala Lumpur, pp. 243-265.

Sulaiman, M. and Zakari, M.A. (2015), "Efficiency and effectiveness of waqf institutions in Malaysia: toward financial sustainability", Bloomsbury Qatar Foundation Journals, Vol. 1, pp. $43-53$.

Sulaiman, N. and Abdul Manaf, F. (2009), "Peranan harta wakaf dalam bidang pembangunan dan pendidikan ummah: fokus dalam bidang perubatan”, Jurnal Pengurusan JAWHAR, Vol. 3 No. 1, pp. 1-30.

Sulaiman, S. (2008), "Islamic legal ruling on the development of waqf khas land from the Sharīah perspective", Jurnal Muamalat, Vol. 1, pp. 45-64.

Sulaiman, S. (2012), "Issues in developing waqf assets via Islamic real estate investment trusts structure in Malaysia: a review”, Jurnal Kanun, Vol. 2, pp. 149-177.

Van Leeuwen, R. (1999), Waqfs and Urban Structures: The Case of Ottoman Damascus, Brill, Leiden.

Wildermuth, D. (2012), How the Smart Money Invests: Wise Money: Using the Endowment Investment Approach to Minimize Volatility and Increase Output, McGraw Hill, New York, NY.

Yale University (2013), Financial Report 2012-2013, Yale University, New Haven.

Yang, A. (2014), "Pembangunan wakaf (perbadanan wakaf negeri Selangor)", paper presented at Seminar Waqaf Antarabangsa, 7-10 December, Kuala Lumpur.

Yayasan Waqaf Malaysia (2016), Waqf Property Development Transformation Master Plan Study in Malaysia, Yayasan Waqaf Malaysia, Putrajaya.

Zarqa, M.A. (1994), "Financing and investment in awqaf projects: a non-technical introduction", Islamic Economic Studies, Vol. 1 No. 2, pp. 55-62.

\section{About the authors}

Syahnaz Sulaiman, $\mathrm{PhD}$, is a Senior Lecturer at the Faculty of Economics and Muamalat, Universiti Sains Islam Malaysia (USIM). Prior to joining USIM, she served as an Senior Assistant Director at the Department of Islamic Development Malaysia (JAKIM). She has been actively involved in preparing numerous research papers and articles on Islamic finance. Syahnaz Sulaiman is the corresponding author and can be contacted at: syahnaz@usim.edu.my

Aznan Hasan, $\mathrm{PhD}$, is an Associate Professor in Islamic law at the Institute of Islamic Banking and Finance, International Islamic University Malaysia (IIBBF). He has served as a Sharīah advisor to various Islamic financial institutions and corporate bodies locally and internationally. He is currently a member of the Sharīah Advisory Council of Securities Commission Malaysia, Chairman of the 
Sharī'ah Committee of Maybank Islamic Berhad and Sharī'ah Consultant to Maybank Investment Bank and Hong Leong Islamic Bank.

Azman Mohd Noor, $\mathrm{PhD}$, is an Associate Professor at the Institute of Islamic Banking and Finance, International Islamic University Malaysia (IIiBF). He has served as a Sharī'ah advisor in Islamic financial institutions namely as the Deputy Chairman of Sharīah Committee of Al-Rajhi Bank Malaysia, Sharīah committee member of Bank Rakyat Malaysia Berhad and Chairman of Sharī'ah Committee, AmMetLife Takaful Berhad.

Muhd Issyam Ismail (Associate, AICB) is a Sharī'ah Trainee at an Islamic bank in Malaysia. He holds a master's degree (MSc) in Islamic Banking and Finance from the Institute of Islamic Banking and Finance, International Islamic University Malaysia (IIBBF) and a Professional Banker Certificate from the Asian Institute of Chartered Bankers.

Nazrul Hazizi Noordin is a $\mathrm{PhD}$ candidate at the International Centre for Education in Islamic Finance (INCEIF), Malaysia. His areas of research interest are financial accounting, corporate governance, Islamic banking, Islamic capital market and social finance.

For instructions on how to order reprints of this article, please visit our website: www.emeraldgrouppublishing.com/licensing/reprints.htm Or contact us for further details: permissions@emeraldinsight.com 